\title{
Strategies and Methodologies of Improving Rice Varieties in Egypt
}

\author{
A. A. Abd Allah, Shimaa A. Badawy* and A. T. Badawi \\ Rice Research Department, Field Crop Research Institute, \\ Agricultural Research Center, Gizza and *Agronomy \\ Department, Faculty of Agriculture, Kafrelsheikh University, \\ Kafrelsheikh, Egypt.
}

\begin{abstract}
T $N$ THE EXPERIMENTAL Farm of the Rice Research and Training Center (RRTC), Sakha, Kafer elshiekh, Egypt, during the period from 2005 to 2011 rice growing seasons. The present investigation was carried out to evaluate some Delta-Med materials under Egyptian conditions and develop a new rice lines using a crosses between 7 Egyptian varieties (Giza 177, Giza 178, Sakha 101, Sakha 102, Sakha103, Sakha 104 and Giza 182) and 7Spain varieties (Bala, Susan, Bahia, Bomba, Montsianejj, Senia and Tebre) to enhance the former genotype yielding ability. The results showed that there were significant differences between Egyptian varieties and Delta-Med varieties as well as among each group itself. The Egyptian varieties exceeded the Delta-Med entries in grain yield and its associated traits. For Spanish and Delta-Med genotypes, they were generally low grain yield, shorter duration and higher 1000-grainweight. With crosses between Egyptian and Spain varieties, the former genotype yielding ability were enhanced along with a specific breeding program to be designed for Spain materials and be evaluated in Spain in the few coming years. The progenies from each cross were advanced under normal conditions with the pedigree method technique. The best selected lines from F6 generation (2010) were promoted to be grown as F7 generation in 2011 season. These lines were found to be resistant to blast disease in addition to possessing useful traits associated with high yielding ability. Phenotypic coefficient of variation (PCV) was high for all the studied character and genotypic coefficient of variability (GCV) showed the same trend as for PCV. Heritability estimates were high for all studied traits. Highly significant positive phenotypic correlation coefficients were determined between grain yield per plant and all yield components studied.
\end{abstract}

Keywords: Rice, Grain, Plant breeding, Yielding, Egypt.

Rice is the most important food crop in the world. Almost half of the world's population depends on rice as their staple food. Rice is the most important crop to directly consume by humans. With around $600 \mathrm{M}$ t produced on $149 \mathrm{M}$ ha in 2003 , rice accounts for $23 \%$ of the world's caloric intake (Khunthasuvon et al., 1998). Rice production increased by 130\% between 1966 and 2000, while the population of low income countries increased by an average of $90 \%$ over the same period. The world population is predicted to reach approximately 8 billion 
by 2030 and there is therefore a need to further increase rice production by $40 \%$ in the next 25 years (IRRI, 1996).

Therefore, to meet the needs of the growing world population, rice production should be increased via developing new high yielding and drought tolerant rice varieties. The rice growing area is about half million hectares with a national average yield of 10 tons/ ha in Egypt. This significantly high productivity is mainly due to the development of short duration varieties with a higher yield potential(10 t/ha), resistance to biotic and a biotic stresses, better grain quality ( high milling and low amylase content) in combine with an excellent extension network through the national campaign of rice (RRTC, 2007).

As a part of the international co-operation with Delta Med countries, an initiative were carried out at the Institute of Agroambiental TerresEbre., Spain, to evaluate six of our newly released varieties, along with four checks in 2005 season. The Egyptian varieties were significantly different in their behavior under Spain conditions. The objectives of the current work are to evaluate some Spain materials under Egyptian conditions and also to start an initiative to develop new anther culture derived lines using crosses between Egyptian and Spain varieties to enhance the former genotype yielding ability. These lines, along with a specific breeding program designed for Spain materials, to be evaluated in Spain in the few coming years.

The objectives of the current work is to evaluate some Delta Med materials under Egyptian conditions and also to develop a new rice lines using a crosses between Egyptian and Spain varieties to enhance the former genotype yielding ability.

\section{Materials}

\section{Materials and Methods}

\section{Parents}

A total of 14 entries including 7 Egyptian varieties i.e, Giza 177, Giza 178, Sakha 101, Sakha 102, Sakha103, Sakha 104 and Giza 182 and 7 spanish ones, namely, Bala, Susan, Bahia, Bomba, Montsianejj, Senia and Tebre.

\section{The pedigree generations of Delta-Med materials}

A pedigree breeding program specifically to the Delta Med materials have reached up to F7 stage in 2011 rice season. The summary of the breeding program with Delta med materials are presented in Table 1 and Table 2. A total of 45 F7 lines were selected according to their desirable characters such as high yielding ability, blast resistance, stem borer resistance, grain weight and grain quality characters. These lines will be promoted to be grown as yield trial experiments in 2012 rice season. One set of this F7 lines will be distributed to be grown in the different locations as a verification trials through technology transfer program and after that can be sent to the Delta Med countries for evaluation there.

Egypt. J. Agron. 34, No.2 (2012) 
TABLE 1. Summary of the pedigree generations of Delta-Med materials (2010).

\begin{tabular}{|l|c|c|c|c|c|}
\hline \multirow{3}{*}{ Year } & \multirow{2}{*}{ Generation } & \multicolumn{2}{|c|}{ Planted } & \multicolumn{2}{c|}{ Selected } \\
\cline { 3 - 6 } & & Lines & Crosses & Lines & Crosses \\
\hline \multirow{2}{*}{2006} & F1 & - & 24 & - & 24 \\
& F2 & 323 & 24 & 286 & 10 \\
\hline \multirow{3}{*}{2007} & F1 & - & 16 & - & 16 \\
& F2 & 500 & 8 & 75 & 7 \\
& F3 & 263 & 10 & 212 & 10 \\
\hline \multirow{3}{*}{2008} & F2 & 380 & 16 & 158 & 15 \\
& F3 & 204 & 7 & 106 & 7 \\
& F4 & 230 & 10 & 115 & 10 \\
\hline \multirow{3}{*}{2009} & F3 & 148 & 14 & 102 & 10 \\
& F4 & 96 & 6 & 134 & 6 \\
& F5 & 110 & 9 & 100 & 8 \\
\hline \multirow{3}{*}{2010} & F4 & 101 & 10 & 85 & 9 \\
& F5 & 128 & 6 & 66 & 3 \\
& F6 & 75 & 3 & 45 & 3 \\
\hline \multirow{2}{*}{2011} & F5 & 85 & 9 & 30 & 9 \\
& F6 & 66 & 3 & 25 & 3 \\
& F7 & 45 & 3 & 6 & 3 \\
\hline
\end{tabular}

TABLE 2. Summary of the pedigree generations of Delta-Med materials (2011).

\begin{tabular}{|l|c|c|c|c|}
\hline \multirow{2}{*}{ Generation } & \multicolumn{2}{|c|}{ Planted } & \multicolumn{2}{c|}{ Selected } \\
\cline { 2 - 5 } & Lines & Crosses & Lines & Crosses \\
\hline F5 & 81 & 9 & 30 & 9 \\
\hline F6 & 43 & 3 & 25 & 3 \\
\hline F7 & 15 & 3 & 6 & 3 \\
\hline Total & 135 & 15 & 61 & 15 \\
\hline
\end{tabular}

\section{Methods}

The present investigation was carried out at the Experimental Farm of the Rice Research and Training Center (RRTC), Sakha, Kafer elshiekh, Egypt during seven successive rice growing seasons (from 2005 to 2011) to evaluate some Delta Med materials under Egyptian conditions and also to develop a new rice lines using a crosses between Egyptian and Spain varieties to enhance the former genotype yielding ability.

The tested materials were grown in randomized complete block design (RCBD) with three replications, each plot were 7 rows $5 \mathrm{~m}$ long with a plant spacing $20 \times 20 \mathrm{~cm}$, the nurseries were raised till age of 30 days, then, they were transplanted with 2-3 seedling per hill. The fertilization was applied as recommended rate and time of application. These genotypes have a wide range 
of variation due to their different genetic background. Data was recorded on the grain yield (tons/ha), heading date (days), no. productive tillers/plant, plant height $(\mathrm{cm})$, panicle length $(\mathrm{cm})$, panicle weight $(\mathrm{g})$, fertility percentage $(\%)$ and 1000 grain weight $(\mathrm{g})$. At first, the data were analyzed by the ordinary analysis of variance to test the significance of differences among the fourteen genotypes. The genotypes mean squares were found to be significant; for all traits studied in their combined data. The combined analysis was calculated over the two years to test the interaction of the different genetic components with the two years as two different environmental conditions. Homogeneity test was done followed by Bartlet (1937) before one proceeds with the computations of the combined experiments and the error variances of the tests were homogenous.

In 2005, seeds of the above mentioned varieties were grown in three successive sowing dates with 10 days intervals to overcome the difference of heading date among them. Thirty days after sowing, seedlings of each variety were individually transplanted in the permanent field in three rows, five meters long and $20 \mathrm{~cm}$ between plants and rows. Crossing was carried out between some Delta-Med varieties and Egyptian parents to produce F1 hybrid seeds. Bulk emasculation method was practiced by using hot water technique. The hybrid seeds were grown in the winter glass house to produce F1 generations and the normal F1 at the experimental farm at 2006. The list of the crosses made during 2005 rice growing season are presented in Table 3. In 2006 season, a total of 24 crosses besides their parents were grown in a randomized complete block design (RCBD) with three replications, each replicate consisted of five rows for each parent and F1 cross. Each row was $5 \mathrm{~m}$ long and contained 25 hills with $20 \mathrm{~cm}$ between rows. Weeds were chemically controlled by applying two liters of Saturn/feddan four days after transplanting. Nitrogen fertilizer was applied as recommended rate and time of application. The crosses listed in Table 3 was designed as to fulfill most of our breeding objectives, i.e., yield potential, resistance to biotic stresses, earliness and grain quality parameters. The hybrid seeds of these crosses were divided in two groups, the first was grown in the winter nursery of the glass house of RRTC to be grown as F2 in the Experimental farm of RRTC in 2006 .The second group was kept to be grown as $\mathrm{F} 1$ generation in 2006. The F1 and F2 crosses were subjected to pedigree method for selection in the segregating generations. This allows additive alleles to be accumulated in such complex traits. The F4, F5 and F6 generations in 2010 which have been grown as F5, F6 and F7 in 2011 rice growing season. The data of each character of each F7 hybrid population (individuals) were analyzed separately by the analysis of variance, according to Panse \& Sukhatme (1957). The genetic parameters, i.e., phenotypic variance, genotypic variance, genetic coefficient of variation was computed according to the formula suggested by Burton (1952). Heritability in broad sense and genetic advance upon selection were computed according to Johanson et al. (1955). 
TABLE 3. List of crosses made during 2005 season between Delta -Med and Egyptian rice varieties .

\begin{tabular}{|lll|}
\hline No. & Crosses & Source \\
\hline 1 & Bahia / Giza 177 & NC $-2005-51$ \\
2 & Bahia / Giza 178 & NC $-2005-79$ \\
3 & Bahia / Sakha 101 & NC $-2005-126$ \\
4 & Bahia / Sakha 102 & NC $-2005-147$ \\
5 & Bahia / Sakha 103 & NC $-2005-172$ \\
6 & Bahia / Sakha 104 & NC $-2005-196$ \\
7 & Bahia / Egyptian Yasmine & NC $-2005-200$ \\
8 & Bahia / Yun Len 18 & NC $-2005-229$ \\
9 & Bahia / Geyhwa 7 & NC $-2005-230$ \\
10 & Bahia / Onpo 1 & NC $-2005-231$ \\
11 & Bahia / GZ 6522-15-1-1-3 & NC $-2005-277$ \\
12 & Bahia / GZ 7842-4-1-3-1 & NC $-2005-317$ \\
13 & Bahia / CT 9852-B-2-1-2-4PM & NC $-2005-359$ \\
14 & Bomba / Giza 177 & NC $-2005-52$ \\
15 & Bomba / GZ 1368-S-5-4 & NC $-2005-100$ \\
16 & Bomba / Sakha 101 & NC $-2005-127$ \\
17 & Bomba / Sakha 102 & NC $-2005-148$ \\
18 & Bomba / Sakha 103 & NC $-2005-173$ \\
19 & Bomba / Sakha 104 & NC $-2005-197$ \\
20 & Bomba / Balado & NC $-2005-228$ \\
21 & Bomba / GZ 6522-15-1-1-3 & NC $-2005-278$ \\
22 & Bomba / GZ 7842-4-1-3-1 & NC $-2005-318$ \\
23 & Bomba / GZ 7456-13-6-5-3- & NC $-2005-335$ \\
24 & Bomba / GZ 7563-20-10-8-1 & NC $-2005-381$ \\
\hline
\end{tabular}

\section{Results and Discussion}

\section{Characters of Delta-Med materials grown}

Results of the evaluation experiment are presented in Table 4. For the $3^{\text {rd }}$ year of evaluation, the Egyptian varieties exceeded the Delta-Med entries in grain yield and its components except 1000 grain weight. All Egyptian varieties exceeded 10 tons / ha. Giza 181 and Sakha 101 recorded the highest grain yield (12.43 and 12.30 ton/ ha, respectively). For Spanish and Delta med genotypes, grain yield were generally low and ranged between 6.57 tons for Tebre and 9.54 tons /ha for Publa. The Delta- Med genotypes had generally shorter duration and higher 1000 grain weight (Table 4). 1000 grain weight (g) for Delta med genotypes ranged from 20.70 in Puntal to 36.10 in 80116-TR259-1-1, while in case of Egyptian rice varieties, 1000 grain weight values ranged from 21.90 in Giza 178 to 28.80 in Sakha 101.

This variation detected among the Egyptian and Delta-Med genotypes will give a great opportunity to enhance the trait value for most of the studied traits by using conventional breeding to utilize such high level of variation among those genotypes. 
TABLE 4. Mean performance data of Delta-Med materials grown at Sakha (2010).

\begin{tabular}{|c|c|c|c|c|c|c|c|}
\hline Genotype & $\begin{array}{c}\text { D.H } \\
\text { (day) }\end{array}$ & $\begin{array}{l}\text { P.H } \\
(\mathbf{c m})\end{array}$ & $\begin{array}{l}\text { P.L } \\
(\mathbf{c m})\end{array}$ & $\begin{array}{l}\text { No.till./ } \\
\text { plant }\end{array}$ & $\underset{\text { (ton/ha) }}{\mathbf{G . y}}$ & $\begin{array}{l}\text { Fert. } \\
(\%)\end{array}$ & $\begin{array}{l}\text { 1000-g-w } \\
\text { (g) }\end{array}$ \\
\hline Giza 177 & 96.00 & 100.00 & 26.00 & 20.33 & 9.98 & 89.10 & 22.30 \\
\hline Giza178 & 98.00 & 102.00 & 24.60 & 28.66 & 10.70 & 94.00 & 21.90 \\
\hline Giza182 & 106.00 & 98.00 & 23.60 & 21.66 & 9.15 & 87.92 & 23.80 \\
\hline Giza 181 & 112.30 & 110.00 & 27.60 & 25.00 & 9.52 & 85.12 & 26.40 \\
\hline Sakha 101 & 111.00 & 91.00 & 19.60 & 29.66 & 11.00 & 93.95 & 28.80 \\
\hline Sakha102 & 98.00 & 107.00 & 28.60 & 26.00 & 9.50 & 95.52 & 27.40 \\
\hline Sakha103 & 94.00 & 104.00 & 26.00 & 22.66 & 9.90 & 86.19 & 22.10 \\
\hline Sakha104 & 106.00 & 108.00 & 26.30 & 27.33 & 10.50 & 93.64 & 27.60 \\
\hline Bala & 94.00 & 95.00 & 22.00 & 25.00 & 9.31 & 95.54 & 30.40 \\
\hline Susan & 94.00 & 74.60 & 21.60 & 23.33 & 7.79 & 96.81 & 27.50 \\
\hline Bahia & 91.00 & 101.00 & 26.30 & 13.00 & 5.10 & 75.70 & 32.30 \\
\hline Bomba & 92.00 & 128.30 & 25.30 & 20.33 & 7.79 & 87.19 & 27.80 \\
\hline Montsianejj & 92.00 & 78.30 & 26.00 & 27.66 & 5.19 & 69.81 & 31.70 \\
\hline Senia & 93.00 & 82.00 & 21.30 & 17.33 & 5.30 & 86.10 & 27.60 \\
\hline Tebre & 84.00 & 77.00 & 21.00 & 19.66 & 6.98 & 87.50 & 30.50 \\
\hline 79004- TR4-4-2-1-1 & 92.00 & 111.00 & 27.00 & 25.33 & 8.09 & 89.03 & 31.10 \\
\hline 79061- TR64-3-3-1-1 & 89.00 & 113.00 & 19.60 & 18.33 & 5.69 & 78.74 & 35.70 \\
\hline 80110- TR 4-1-1 & 115.00 & 110.00 & 22.00 & 13.00 & 4.58 & 71.11 & 34.20 \\
\hline 80116- TR 259-1-1 & 92.00 & 99.30 & 20.00 & 16.00 & 5.53 & 78.65 & 36.10 \\
\hline $\begin{array}{l}96066-\text { TR 1805-5- } \\
1-1\end{array}$ & 95.00 & 102.60 & 18.60 & 10.00 & 2.88 & 67.09 & 30.10 \\
\hline Publa & 96.00 & 98.00 & 27.30 & 11.66 & 3.91 & 67.16 & 23.30 \\
\hline Hispgran & 92.00 & 106.00 & 19.30 & 18.30 & 4.11 & 88.88 & 32.80 \\
\hline Thaibonet & 98.00 & 90.60 & 21.30 & 22.00 & 6.00 & 80.42 & 31.00 \\
\hline Puntal & 103.00 & 95.00 & 25.00 & 25.00 & 7.47 & 90.90 & 20.70 \\
\hline LSD at 0.05 & 2.50 & 2.90 & 2.30 & 2.55 & 0.70 & 5.00 & 2.20 \\
\hline
\end{tabular}

$\mathrm{DH}=$ Days to heading, P.H= Plant height, $\mathrm{P} . \mathrm{L}=$ Panicle length, No.till.=No. productive tillers/plant, G.y $=$ Grain yield(ton/ha), Fert. $=$ Fertility $\%$ and $1000-\mathrm{g}-\mathrm{w}=1000$ grain weight. The same as below.

Biotic stress reaction of the Delta-Med tested materials

As far as biotic stresses is concerned, Egyptian varieties exhibit also considerably higher level of resistance. The reaction of the tested materials to both blast and stem borer are presented in Table 5. Egyptian rice varieties showed higher level of resistance to blast at both leaf and nick infection except Sakha 101 and Sakha 104. These two varieties started to show a blast resistance breakdown during the last three years. Most of the Delta Med showed high level of susceptibility which may limit their use under such ecosystem. 
TABLE 5. Biotic stress reaction of the Delta-Med tested materials under Egyptian conditions (2010).

\begin{tabular}{|c|c|c|c|c|}
\hline No. & Genotype & $\begin{array}{c}\text { Blast Reaction } \\
\text { (leaf) }\end{array}$ & $\begin{array}{c}\text { Blast Reaction } \\
\text { (nick) }\end{array}$ & $\begin{array}{c}\text { Stem Borer } \\
\text { Reaction }\end{array}$ \\
\hline 1 & Giza 177 & 1 & 1 & $\mathrm{R}$ \\
\hline 2 & Giza 178 & 1 & 1 & MR \\
\hline 3 & Giza 181 & 1 & 1 & $\mathrm{R}$ \\
\hline 4 & Giza182 & 1 & 1 & $\mathrm{R}$ \\
\hline 5 & Sakha 101 & 4 & 4 & S \\
\hline 6 & Sakha 102 & 1 & 1 & $\mathrm{R}$ \\
\hline 7 & Sakha 103 & 1 & 1 & $\mathrm{R}$ \\
\hline 8 & Sakha 104 & 5 & 4 & $S$ \\
\hline 9 & Bala & 7 & 7 & HS \\
\hline 10 & Susan & 7 & 7 & $\mathrm{~S}$ \\
\hline 11 & Bahia & 7 & 7 & HS \\
\hline 12 & Bomba & 7 & 7 & $\mathrm{~S}$ \\
\hline 13 & Montsianeji & 7 & 7 & HS \\
\hline 14 & Senia & 7 & 7 & HS \\
\hline 15 & Tebre & 5 & 7 & HS \\
\hline 16 & 79004-TR4-4-2-1-1 & 5 & 7 & $\mathrm{~S}$ \\
\hline 17 & 79061-TR64-3-3-1-1 & 7 & 7 & S \\
\hline 18 & 80110- TR 4-1-1 & 7 & 7 & $S$ \\
\hline 19 & 80116- TR 259-1-1 & 5 & 5 & HS \\
\hline 20 & 96066- TR1805-5-1-1 & 5 & 5 & $\mathrm{~S}$ \\
\hline 21 & Publa & 7 & 7 & $S$ \\
\hline 22 & Hispgran & 5 & 7 & $\mathrm{~S}$ \\
\hline 23 & Thaibonet & 7 & 7 & HS \\
\hline 24 & Puntal & 7 & 7 & $\mathrm{~S}$ \\
\hline
\end{tabular}

$\mathrm{R}=$ Resistant, $\mathrm{MR}=$ Moderate resistant , $\mathrm{S}=$ Susceptible and $\mathrm{HS}=$ Highly susceptible

Characters of the best selected lines (15 lines) from F6 generation

Data from Table 6 shows that most of the selected lines have desirable values for various traits. The red color lines were superior for most of the studied traits especially for yield and its components. These lines exceeded their parental lines. In addition to its higher yield they were earlier in heading and growth duration around 130 days, heavier in grain weight, high fertility percentage. So, we have succeeded to combine Egyptian and Delta-Med desirable traits in one line. These were promoted to be grown as F7 generation in 2011 rice growing season under normal conditions besides the Egyptian rice varieties for comparison. The Selection has been made for yield and its components as well as blast and stem borer resistance. 
TABLE 6. The best selected lines (15 lines) from F6 generation (2010).

\begin{tabular}{|c|c|c|c|c|c|c|c|c|}
\hline No. & Crosses & $\begin{array}{c}\text { D.H } \\
\text { (day) }\end{array}$ & $\begin{array}{c}\text { P.H } \\
(\mathbf{c m})\end{array}$ & $\begin{array}{c}\text { P.L } \\
(\mathbf{c m})\end{array}$ & $\begin{array}{c}\text { No.till./ } \\
\text { plant }\end{array}$ & $\begin{array}{c}\text { G.y } \\
\text { (ton/ha) }\end{array}$ & $\begin{array}{c}\text { Fert. } \\
(\boldsymbol{\%})\end{array}$ & $\begin{array}{c}\text { 1000-g-w } \\
(\mathbf{g})\end{array}$ \\
\hline 7 & & 99.00 & 93.00 & 20.00 & 21.00 & 7.90 & 87.00 & 23.00 \\
18 & & 102.00 & 91.00 & 19.00 & 25.00 & 10.58 & 88.00 & 25.00 \\
21 & & 100.00 & 102.00 & 20.00 & 22.00 & 10.45 & 90.00 & 26.00 \\
25 & & 100.00 & 100.00 & 19.00 & 19.00 & 8.89 & 91.00 & 26.00 \\
26 & & 99.00 & 95.00 & 21.00 & 26.00 & 10.87 & 93.00 & 26.00 \\
27 & Bomba x & 99.00 & 110.00 & 23.00 & 19.00 & 9.19 & 89.00 & 25.00 \\
28 & Giza182 & 100.00 & 88.00 & 22.00 & 20.00 & 8.02 & 86.00 & 25.00 \\
29 & & 101.00 & 97.00 & 27.00 & 30.00 & 11.22 & 92.00 & 27.00 \\
30 & & 100.00 & 105.00 & 25.00 & 29.00 & 11.38 & 94.00 & 28.00 \\
39 & & 100.00 & 100.00 & 26.00 & 22.00 & 8.49 & 87.00 & 26.00 \\
44 & & 100.00 & 90.00 & 28.00 & 28.00 & 11.00 & 92.00 & 29.00 \\
53 & Bomba x & 100.00 & 93.00 & 25.00 & 24.00 & 10.75 & 94.00 & 27.00 \\
54 & IR6554-22- & 99.00 & 98.00 & 24.00 & 31.00 & 11.14 & 91.00 & 28.00 \\
56 & $2-3$ & 98.00 & 105.00 & 23.00 & 30.00 & 11.03 & 90.00 & 27.00 \\
65 & Susan x & 99.00 & 100.00 & 22.00 & 18.00 & 7.90 & 88.00 & 25.00 \\
\hline
\end{tabular}

Phenotypic correlation coefficients

Phenotypic correlation coefficients among the traits studied are shown in Table 7. Days to heading is significantly and highly significantly and positively associated with no. panicles/plant and fertility \%. Plant height was positively and significantly associated with panicle length. Panicle length was highly significantly and positively correlated with grain yield per plant. No. panicles/plant was positively correlated with grain yield per plant and fertility $\%$. One thousand grain weight and fertility percentage were significant and positively correlated with grain yield per plant. These results were in agreement with those reported by Bhattacharyya \& Ghosh (2004), Shashidhar et al. (2005), Surek \& Beser (2003) and Yogameenakshi et al. (2004).

TABLE 7. Correlation coefficients among the traits studied of the selected lines from

F7 generation.
\begin{tabular}{|l|c|c|c|c|c|c|c|}
\hline \multicolumn{1}{|c|}{ Characters } & D.H & P.H. & P. L & $\begin{array}{c}\text { No.panicle/ } \\
\text { plant }\end{array}$ & Fert. & $\begin{array}{c}\text { 1000- } \\
\text { g-w }\end{array}$ & $\begin{array}{c}\text { Grain } \\
\text { yield /plant }\end{array}$ \\
\hline D.H. & 1.000 & 0.230 & 0.310 & $0.520^{* *}$ & $0.220^{*}$ & 0.180 & 0.300 \\
P.H. & & 1.000 & $0.780^{* *}$ & 0.110 & -0.220 & 0.250 & 0.280 \\
P.L. & & & 1.000 & 0.150 & 0.310 & 0.230 & $0.550^{*}$ \\
No.panicles & & & & 1.000 & $0.475^{*}$ & 0.210 & $0.780^{* *}$ \\
/plant & & & & & 1.000 & 0.225 & $0.650^{* *}$ \\
Fert. & & & & & & 1.000 & $0.850^{* *}$ \\
1000-g-w & & & & & & & 1.000 \\
Grainyield/plant & & & & & & & \\
\hline
\end{tabular}

*Significant and ** highly significant 


\section{Genetic components}

In general, the phenotypic coefficient of variation (PCV), (Table 8) was high for fertility \% (110.00), number of panicles per plant (100.00), and plant height (98.00), while it was low for panicle length (40.00), days to heading (50.00) and grain yield/plant (55.00). Genotypic coefficient of variation GCV showed the same trend but the corresponding values were lower thereby implying the influence of environment on the genotypes. Heritability estimates, in general, were moderate to high for all characters studied, the values ranged from $62.00 \%$ to $76.53 \%$. Reasonable values of genetic advance were found for all traits studied; implying that higher proportion of genotypic variance was attributed to additive genetic variance, and therefore, selection would be effective and useful for these traits from the progenies which will be produced. Sheeba (2005) and Raju et al. ( 2004) reported the same results with the other varieties.

TABLE 8. Genetic parameters of variation for some characters studied in the promising lines.

\begin{tabular}{|l|c|c|c|c|}
\hline Characters & $\begin{array}{c}\text { Genotypic } \\
\text { variance } \\
(\%)\end{array}$ & $\begin{array}{c}\text { Phenotypic } \\
\text { variance(\%) }\end{array}$ & $\begin{array}{c}\text { Heritability in } \\
\text { broad sense(\%) }\end{array}$ & $\begin{array}{c}\text { Genetic } \\
\text { advance }\end{array}$ \\
\hline Days to heading(day) & 35.00 & 50.00 & 70.00 & 10.19 \\
Plant height(cm) & 75.00 & 98.00 & 76.53 & 15.50 \\
Panicle length(cm) & 25.00 & 40.00 & 62.50 & 8.07 \\
No. panicles/plant & 68.10 & 100.00 & 68.00 & 14.00 \\
100 grain weight (gram) & 66.00 & 86.00 & 76.74 & 14.51 \\
Fertility (\%) & 85.00 & 110.00 & 77.27 & 16.63 \\
Grain yield(ton/ha) & 38.00 & 55.00 & 69.00 & 10.54 \\
\hline
\end{tabular}

The best five lines are presented in Table 9. These lines can be distributed at the different rice growing areas in Egypt as well as can be tested at the DeltaMed conditions to be used as a donor parents in rice breeding program or as new rice varieties directly possess high yielding ability, good grain quality characters and blast and stem borer resistance.

TABLE 9. The best selected lines (5 lines) from F7 generation (2011).

\begin{tabular}{|c|c|c|c|c|c|c|c|c|}
\hline No. & Crosses & $\begin{array}{c}\text { D.H } \\
\text { (day) }\end{array}$ & $\begin{array}{l}\text { P.H } \\
(\mathbf{c m})\end{array}$ & $\begin{array}{l}\text { P.L } \\
(\mathrm{cm})\end{array}$ & $\begin{array}{l}\text { No.till/ } \\
\text { plant }\end{array}$ & $\begin{array}{c}\text { G.y } \\
\text { (ton/ha) }\end{array}$ & $\begin{array}{l}\text { Fert. } \\
(\%)\end{array}$ & $\begin{array}{l}\text { 1000-g- } \\
\text { w (g) }\end{array}$ \\
\hline 26 & \multirow{4}{*}{$\begin{array}{l}\text { Bomba x } \\
\text { Giza182 }\end{array}$} & 100.00 & 98.00 & 22.00 & 24.00 & 10.71 & 90.00 & 26.00 \\
\hline 29 & & 103.00 & 100.00 & 25.00 & 27.00 & 11.18 & 90.00 & 27.00 \\
\hline 30 & & 98.00 & 107.00 & 23.00 & 28.00 & 11.00 & 91.00 & 28.00 \\
\hline 44 & & 100.00 & 93.00 & 26.00 & 25.00 & 10.60 & 92.00 & 29.00 \\
\hline 53 & \multirow{2}{*}{$\begin{array}{c}\text { Bomba x } \\
\text { IR6554-22-2-3 }\end{array}$} & 102.00 & 90.00 & 25.00 & 22.00 & 10.50 & 92.00 & 27.00 \\
\hline 56 & & 95.00 & 100.00 & 23.00 & 28.00 & 11.00 & 90.00 & 27.00 \\
\hline
\end{tabular}

\section{Conclusion}

Data obtained from this study show that most of the selected lines have desirable values for various traits. Some lines were superior for most of the studied traits especially for yield and its components.These lines exceeded their 
parental lines. In addition to its higher yield they were earlier in heading and growth duration around 130 days, heavier in grain weight, high fertility percentage. So, we have succeeded to combine Egyptian and Delta-Med desirable traits in one line. Now we have promising lines from the advanced population's posses many desirable traits. Results of this cooperation will support development in the Mediterranean area and Delta Med areas. We are going to select the most promising lines from the advanced generation to be grown under different locations in some Delta Med countries to test their performance for grain yield, stem borer and blast resistance.

\section{References}

Bhattacharyya, S. and Ghosh,S.K. (2004) Association among yield related traits of twenty four divers land races of rice. Crop Res. 27, 90-93.

Bartlett, M.S. (1937) Properties of sufficiency and statistical tests. Proc.Roy.Soc., London Series A 160, pp. 268-282.

Boonjung, H. and Fukai, S. (1996) Effect of soil water deficit at different growth stage on rice growth and yield under upland conditions. Field Crops Res.48ss, pp.47-55.

Burton, G.W. and Devane, E.H. (1952) Estimating heritability in tall fescue from replicated clonal material. Agron. J. 45, 478-841.

International Rice Research Institute (1996) Standard Evaluation System of Rice

Jacob, W. Kijne (2006) A biotic stress and water scarcity: Identifying and resolving conflicts from plant level to global level. Field Crops Research 97, 3-18.

Johanson, H.W., Robinson, H.F. and Comstock, R.F. (1955) Estimates of genetic and environmental variability in Soybeans. Agron. J. 47, 314-318.

Khunthasuvon, S., Rajatasereekul,S., Hanviriyapant, P. and Basnayake,J. (1998) Effects of fertilizer application and irrigation on grain yield of several rice cultivars. Field Crops Res. 59, 99-108.

Panse and Sukhatme (1957) "Statistical Methods for Agriculture Workers". India Council of Agric. Res. New Delhi, India.

Raju, C.H.S., Rao, M.V.B. and Sundarshanam, A. (2004) Genetic analysis and character association in F2 generation of rice. Madras Agric. J. 91, 66-69.

RRTC (2007) The $11^{\text {th }}$ Annual Workshop of the National Rice Research Program, Rice Research and Training Center, Sakha, Egypt, Jan., 22 ${ }^{\text {nd }}$, 2008.

Shashidhar, H. E., Pasha, F., ManjunathJanamatti, M. S. Vinod and Adnan Kanbar (2005) Correlation and path coefficient analysis in traditional cultivars and doubled haploid lines of rainfed lowland rice (Oryza sativa L.). Oryza, 42,156-159. 
Sheeba, A. (2005) Genetic studies on drought tolerance and stability of Temperature Sensitive Genic Male Sterility (TGMS) based rice hybrids. Ph.D. Thesis, TNAU, Coimbatore.

Surek, H. and Beser, N. (2003) Correlation and path analysis for some yield related traits under rainfed condition. Turkish J. Agric. Forestry, 27, 77-83.

Yogameenakshi, P., Nadarajan, N. and Anbumalarmathi, J. (2004) Correlation and path analysis on yield and drought tolerant attributes in rice (Oryza sativa L.). under drought stress. Oryza, 41, 68-70.

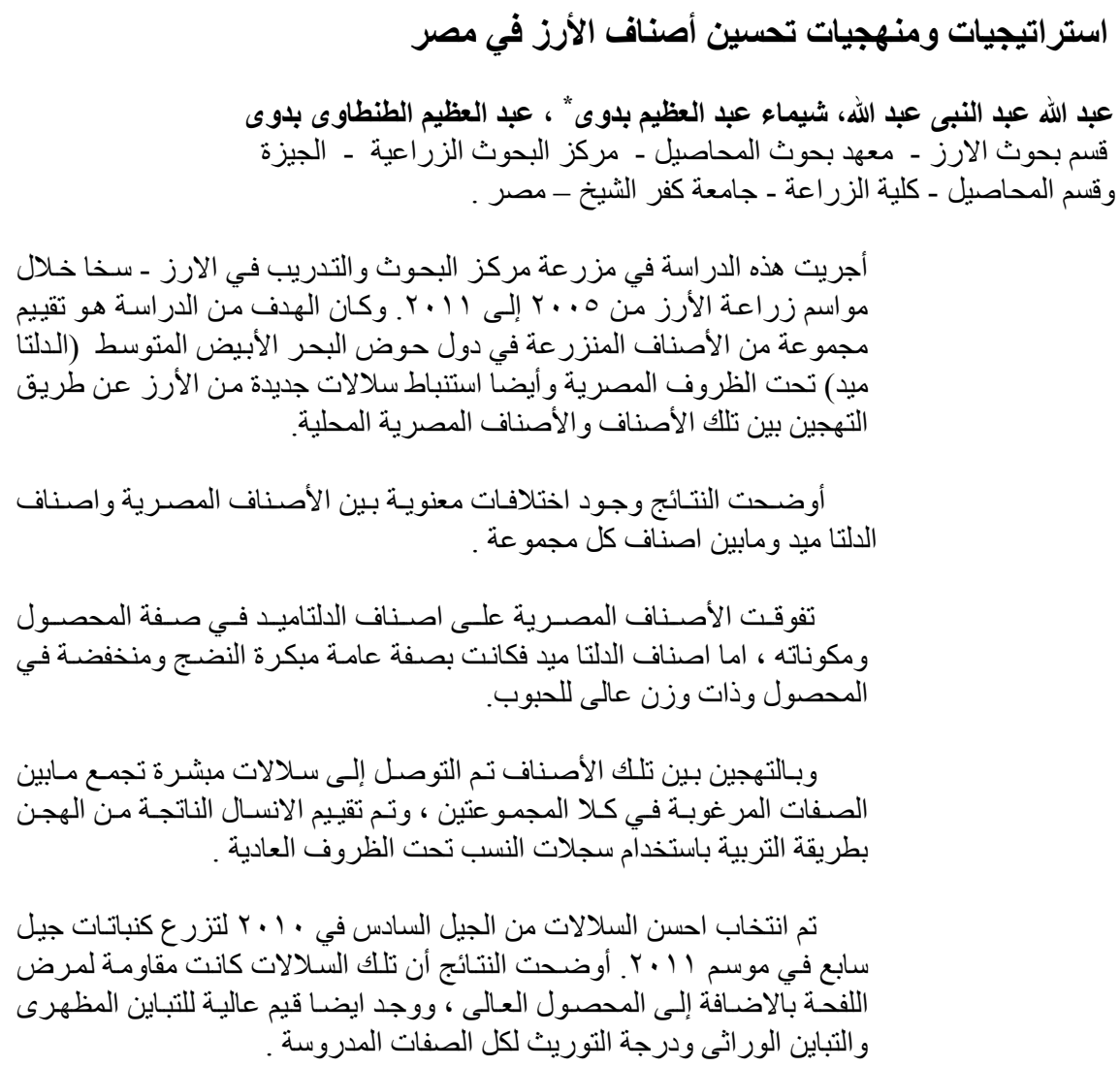

